\title{
Computer Applications
}

For what purposes can microcomputers be used? Here are a few:

\author{
Commercial and business (the electronic office) \\ Stock control \\ Invoicing, order and data processing \\ Police records \\ Word processing \\ Banking
}

\section{Scientific}

Mathematical calculations

Statistics and graphical display

Operational research

Medical data storage and diagnosis

Industrial (the automatic factory)

Process control

Traffic control

Steel and motor vehicle production control

Robotics

\section{Education}

Visual aids

Computer-assisted learning

Teaching the disabled

Timetabling

Pupil records

Careers advice (JIIGCAL)

Biology/Geography/History simulations

Language training

Library records

Leisure and home (the home computer)

Games and music

Burglar alarms

Cooking and housekeeping

Budgetry control

Theatre-lighting control

The basic system of figure 1.1 will satisfy most of these needs, except for the possible addition of high-density memory storage for data processing applications and interfacing devices for industrial control. Part 2 describes how programs might be constructed for many applications, and part 3 how the computer can control the outside world. 